\title{
EDUCAÇÃO E “RAÇA” (ETNIA): PERCEPÇÕES DE EDUCADORES DOS ANOS INICIAIS DA REDE PÚBLICA DE ENSINO DO DISTRITO FEDERAL
}

\author{
Francisco Thiago SILVA ${ }^{1}$ \\ Maria Helena da Silva CARNEIRO ${ }^{2}$ \\ Lívia Freitas Fonseca BORGES ${ }^{3}$
}

RESUMO: Este artigo apresenta os resultados de uma pesquisa que articulou teorias e manifestações sobre as várias concepções do termo "raça" ao longo da história da humanidade, sobretudo na ótica da biologia geneticista, mas que não foi hegemônica, e das manifestações sócio-históricas do conceito, tendo como pano de fundo a historiografia do povo afro-brasileiro e as tentativas de hierarquização raciais ocorridas no Brasil. O estudo foi feito por meio de revisão bibliográfica e metodologicamente com aplicação de questionários em uma escola da Rede Pública de ensino do Distrito Federal, Brasil. O assunto foi abordado sob a ótica reflexiva de autores como: Barbujani (2007), Diwan (2011), Munanga (2003), Gomes (2000, 2005) e Filice (2011). O instrumento de pesquisa utilizado foi o questionário que conteve a técnica da associação livre, em seguida a hierarquização sucessiva de Abric (2001). O objetivo foi tentar identificar as percepções de oito professoras dos Anos Iniciais do Ensino Fundamental da Rede Pública a cerca do conceito "raça” (etnia). O resultado apontou o uso da terminologia raça como sendo ainda associada às diferentes características dos povos que formaram o Brasil. No entanto apontamos a possibilidade do uso de etnia para minimizar as diferenças étnico-raciais que ainda imperam na sociedade brasileira.

PALAVRAS-CHAVE: Raça. Etnia. Hierarquização. Anti-racismo.

\section{Introdução}

As controvérsias que envolvem os múltiplos conceitos de "raça” acompanharam muitas pesquisas Rodrigues (1977); Gobineau (1967); Penka (1883); Munanga (2003) e Barbujani (2007), desde o campo da biologia, passando pela antropologia até a educação.

Ao longo dos séculos XIX e XX inúmeras teorizações sobre o tema foram desenvolvidas, ampliadas e divulgadas, boa parte desenvolvida na Europa e Estados Unidos, que de certa forma influenciaram o imaginário científico social nacional, refletindo numa desigualdade de oportunidades entre os grupos que compõem a

\footnotetext{
${ }^{1}$ Mestre em Educação. UnB - Universidade de Brasília. Faculdade de Educação - Programa de PósGraduação em Educação. Brasília - DF - Brasil. 70910-900 - fthiago2002@yahoo.com.br.

${ }^{2}$ UnB - Universidade de Brasília. Faculdade de Educação - Departamento de Métodos e Técnicas Brasília - DF - Brasil. 70910-900 - mhsilcar@unb.br.

${ }^{3}$ UnB - Universidade de Brasília. Faculdade de Educação - Departamento de Métodos e Técnicas. Brasília - DF - Brasil. 70910-900 - liviaborges@fe.unb.br.
} 
população de nosso país, sobretudo a metade dela, pretos e pardos. ${ }^{4}$ Pretendemos, portanto, nesse artigo identificar e analisar as representações do conceito de etnia (raça) construído por profissionais da educação que atuam nos anos iniciais do Ensino Fundamental.

Justifica-se o estudo, por múltiplos motivos, o principal é entender porque teorias de cunho racistas, estrangeiras e nacionais, ainda corroboram para justificar o racismo velado, essa cordialidade racial, e ainda o "mito de democracia racial" ${ }^{5}$, que envolve o imaginário de muitos brasileiros a ponto de servirem como explicações para as mazelas sociais que acompanham a trajetória dos negros escravizados e de seus descendentes.

A história do Brasil foi construída lado a lado com a do negro, mas desde sua abolição, a liberdade tão perseguida e agora conquistada não veio, no sentido propriamente dito da palavra. O ex-escravizado continuou à margem social e viu nos anos posteriores, pesquisadores desenvolverem as mais diversas teorias de cunho racista, que no fundo foram justificativas para o preconceito de cor que cada descendente dos negros sofreu e ainda vive no seu próprio país. Uma das teses mais conhecidas foi elaborada pelo médico legista Nina Rodrigues em 1894, segundo ele,

O negro, principalmente, é inferior ao branco, a começar da massa encefálica, que pesa menos, e do aparelho mastigatório que possui caracteres animalescos, até as faculdades de abstração, que nele é tão pobre e fraca. Quaisquer que sejam as condições sociais em que se coloque o negro, está ele condenado pela sua própria morfologia e fisiologia a jamais poder igualar o branco (RODRIGUES, 1977, p.268).

A citação acima expressa o que pensava o médico maranhense Raimundo Nina Rodrigues, para justificar, segundo ele a inferioridade do negro, uma espécie de racismo científico. Foi com esse tipo de opinião excludente que a sociedade brasileira foi sendo alicerçada, principalmente no tocante às questões de raça e classe.

Essa pesquisa realizada pelo legista brasileiro sofreu larga influência das teorias de Gobineau (1967), Penka (1883) e outros europeus que buscaram comprovar a

\footnotetext{
${ }^{4}$ Adotaremos o termo negro, para falar desse contingente populacional do Brasil, que segundo o IBGE representa a metade da população brasileira em números, incluindo-se pretos e pardos. Disponível em: $<$ http://seriesestatisticas.ibge.gov.br/series.aspx?vcodigo=POP106\&sv=32\&t=populacao-presente-eresidente-por-cor-ou-raca-dados-do-universo-e-dados-da-amostra>. Acesso em: 4 fev. 2014.

${ }^{5}$ Essa terminologia foi cunhada por Gilberto Freyre (1998), na obra Casa Grande e senzala, publicada originalmente em 1993. No texto o autor defendia que o Brasil por possuir uma imensa quantidade de povos formadores, poderia viver em uma tranqüila sociedade democrática sócio-racial.
} 
superioridade da raça branca, representada pelos arianos (povos nórdicos) e a suposta inferioridade dos africanos.

Nossa sociedade foi construída sob a ótica cultural européia, desde a colonização, os brasileiros foram treinados e incentivados a valorizarem tudo o que fosse feito na Europa, ao mesmo tempo tiveram que negar as produções e mesmo a coexistência com outras culturas como a indígena e africana.

Os negros em nosso território foram vistos como mera mercadoria, pertencente a um grupo inferior, às vezes exclusivamente com justificativas baseadas na quantidade e intensidade de melanina que cada um carregava na própria pele.

Estudiosos da história, como Oliva (2007) [conferir datas, na referência consta 2007] descreve como a visão do negro ficou introjetada em nosso imaginário: os africanos e seus descendentes são tratados como se fossem incapazes, atrasados, preguiçosos, sem educação, desorganizados e inferiores.

Esse modelo monocultural foi fundamental para colocar a raça como mecanismo de seleção natural e fez com que os afro-descendentes, mesmo após a liberdade, continuassem as margens de uma sociedade que tentou a todo custo branqueá-lo e fazendo várias investidas para tentar apagar sua identidade e riscar da nossa história a marca e a presença fundamental dos negros africanos trazidos para cá e de seus descendentes.

Chegamos ao problema motivador desta pesquisa: Qual é a percepção das professoras dos Anos Iniciais do Ensino Fundamental do Distrito Federal sobre o conceito de "raça" (etnia)? Tentaremos responder ao longo dos escritos, partindo da contextualização da origem do uso do termo "raça”.

\section{A construção e desconstrução biológica do conceito de "raça"}

A etimologia do termo raça veio do italiano razza e do latim ratio, que denotavam para sorte, categoria e espécie. Nas ciências naturais o termo apareceu na Zoologia e na Botânica no intuito de classificar algumas espécies de animais e vegetais. Na Suécia o naturalista Linné (1788 apud MUNANGA, 2003) usou a terminologia raça para elaborar uma classificação entre plantas.

No período medieval a raça aparece como descendência, linhagem, grupo ancestral, que possuem características físicas comuns. Já em 1684 François Bernier usa o termo na França para classificar a diversidade humana em grupos, que ele chamou de raça. 
Porém o estudo mais difundido que contempla o sentido posterior conceitual de raça, foi liderado pelo diplomata e escritos francês Arthur de Gobineu, com a publicação da obra "Ensaio sobre a desigualdade de raça humana: raças branca, amarela e negra.”, em 1835. Nesta obra ele defende a supremacia do europeu, especificamente os descendentes da raça ariana, a mais pura e nobre, que configuraria o ápice da evolução humana.

Verificamos o fato de que o mau uso do termo foi amplamente propagado em diversas sociedades do globo e influenciaram a organização social e econômica de diversas nações além de alimentar o imaginário das pessoas que em muitos momentos da nossa história reforçaram o uso de raça para hierarquizar grupos pelas características morfológicas, mesmo a ciência biológica a tendo desconstruído, afinal,

A descoberta de que do ponto de vista biológico não existe raça não significa que as pessoas mudam suas representações sociais de acordo com as últimas descobertas científicas, nem tampouco significa que elas não utilizem essa categoria no seu dia-a-dia. Ao contrário, a despeito da genética revelar que as diferenças entre um negro, um branco e um oriental são ínfimas a ponto de não fazer sentido falar em raça, as pessoas continuam a efetuar classificações e hierarquizações entre os seres humanos em virtude de traços morfológicos (BERNARDINO, 2004, p. 19).

Voltando ao retrospecto, verificamos que Chamberlain (1923), próximo de Hitler, reforça isso ao afirmar que uma espécie humana superior ainda existia na Europa. No intuito de cristalizar essa corrente teórica, o etnólogo alemão Karl Penka (1883) elenca as características físicas da raça superior ariana: homem louro, com olhos azuis e crânio alongado e com um olhar fixo voltado para o futuro. Na Inglaterra, o antropólogo alemão Theodor Posch (1878) ampliou esse debate, ao atribuir as características nórdicas a essa raça ariana.

Décadas mais tarde com a evolução do pensamento cientifico e tecnológico a Biologia recolocou o ser humano na condição de "raça” única, caindo por terra à conceituação diferencial de raça para classificar a humanidade, no entendimento do antropólogo Munanga:

Combinando todos esses desencontros com os progressos realizados na própria ciência biológica (genética humana, biologia molecular, bioquímica), os estudiosos desse campo de conhecimento chegaram a conclusão de que a raça não é uma realidade biológica, mas sim apenas um conceito aliás cientificamente inoperante para explicar a 
diversidade humana e para dividi-la em raça. Ou seja, biologicamente e cientificamente, as raças não existem (MUNANGA, 2003, p.3).

No seio da própria biologia, foi onde a ciência se encarregou de desconstruir o conceito de múltiplas raças humanas, na obra "A invenção das raças", o geneticista Barbujani (2007) apresenta argumentos que demonstram que só há uma raça humana, que nossa espécie não é uma miscelânea de grupos, biologicamente muito distintos, e mais: somos jovens no planeta e viemos da África,

Com toda a probabilidade, os europeus e asiáticos contemporâneos descendem somente das populações que, entre 50 e 100 mil anos atrás, saíram da África, enquanto os que estavam antes se extinguiram. No que diz respeito à biodiversidade humana em seu conjunto, a ausência de raças pode ser explicada precisamente à luz do fato de que somos uma espécie jovem e móvel, quando se requer tempo e isolamento reprodutivo para que se formem grupos geneticamente distintos (BARBUJANI, 2007, p.123).

Muitas características distintas entre grupos humanos no globo terrestre são o resultado de adaptações geográficas, não servindo para confirmar a existência de diferentes raças humanas, embora haja inúmeras variações morfológicas, são as conclusões a que chegaram o médico geneticista Pena e a bióloga Bortolini (2004), ao relatarem criticamente o resultado de uma pesquisa que utilizou o instrumental da genética molecular e da genética de populações para discutir as conseqüências da presença africana na construção da população brasileira, segundo eles,

As grandes similaridades entre todos os humanos, e que nos distinguem com facilidade dos demais primatas, reportam, como visto acima, à nossa origem recente como espécie. Por outro lado, existem múltiplas variações morfológicas, tais como a Cor da pele, a altura, a textura do cabelo e as características faciais, especialmente quando são comparados indivíduos pertencentes aos diferentes grupos nativos continentais (ninguém confundiria um africano de Botswana com um europeu da Noruega ou ainda um índio Yanomami). Repetimos: tais diferenças refletem apenas a adaptação evolutiva das populações geograficamente diversificadas de Homo sapiens ao seu hábitat e não servem para atestar a existência de raças dentro de nossa espécie (PENA; BORTOLINI, 2004, p.34).

Apesar de a biologia já ter chegado a essas conclusões é preciso atentar para um fato: um grande problema para a realidade social brasileira não é a classificação populacional em raças, mas sua hierarquização. 
É nesse sentido que o conceito de raça amplia-se da biologia e da genética e encontra campo nas ciências humanas, principalmente a antropologia e a sociologia, e agora na educação. O uso generalizado sustenta uma perigosa armadilha ideológica que explica a condição inferior que muitos grupos no Brasil viveram e vivem historicamente, a população negra é a que nos interessa neste estudo, caracterizada teoricamente não como uma raça, mas como um variado conjunto de etnias no Brasil, originárias de diferentes pontos do continente africano, antes de continuar as reflexões, é necessário que se conheça a história, os usos e as discussões a respeito do termo etnia.

\section{Pensando em etnia}

A provável origem do termo “etnia” vem do grego ethnikos, que se deriva de ethnos, significando gente ou nação estrangeira. Outra retomada deste conceito aconteceu no século XIX por meio dos estudos do antropólogo Vacher de Lapouge que em 1886 associou povo, raça e nação a terminologia.

No dicionário ${ }^{6}$ o termo aparece como: "Grupo de famílias em uma área geográfica variável, cuja unidade repousa na estrutura familiar, econômica e social comum, e na cultura comum”.

Observamos que raça e etnia aparecem na literatura atual com significados diferentes. O primeiro diz respeito à morfologia e biologia, principalmente na categorização de animais do tipo eqüinos e caninos. Já o segundo apresenta-se relacionado a um conjunto de características sócio-histórico-culturais presentes em determinados grupos humanos, Munanga (2003) nos ajuda a elucidar essa diferença conceitual, segundo ele:

O conteúdo da raça é morfo-biológico e o da etnia é sócio-cultural, histórico e psicológico. Um conjunto populacional dito raça "branca", "negra" e "amarela", pode conter em seu seio diversas etnias. Uma etnia é um conjunto de indivíduos que, histórica ou mitologicamente, têm um ancestral comum; têm uma língua em comum, uma mesma religião ou cosmovisão; uma mesma cultura e moram geograficamente num mesmo território. Algumas etnias constituíram sozinhas nações. Assim o caso de várias sociedades indígenas brasileiras, africanas, asiáticas, australianas, etc. que são ou foram etnias nações. (MUNANGA, 2003, p.7)

\footnotetext{
${ }^{6}$ Disponível em: <http://www.dicio.com.br/etnia/>. Acesso em: 4 fev. 2014.
} 
Com o desenvolvimento da genética e da biologia molecular, tornou-se possível estabelecer conexões ainda que remotas com ancestrais de variados continentes, fazendo-se testes com o número apropriado de marcadores genéticos.

Desses grupos continentais distintos, devido a histórias evolucionárias, sua própria estrutura genética tornou-se diferente, ou seja, existem mais trocas de partes entre o material genético de africanos do que no de europeus ou asiáticos, segundo Salzano (2007) a explicação para isso é “[...] simples: toda a humanidade teve seu berço na África, para horror dos racistas. Portanto, no continente africano, houve mais tempo para a ocorrência de trocas genéticas” (SALZANO, 2007, p.1).

O uso do termo "raça”, ainda usado para animais domésticos, não se sustenta para os seres humanos, pois para Santos et al. (2010):

O genoma humano é composto de 25 mil genes. As diferenças mais aparentes (cor da pele, textura dos cabelos, formato do nariz) são determinadas por um grupo insignificante de genes. As diferenças entre um negro africano e um branco nórdico compreendem apenas 0,005\% do genoma humano. Há um amplo consenso entre antropólogos e geneticistas humanos de que, do ponto de vista biológico, raças humanas não existem (SANTOS et al., 2010, p.122).

Ainda retomando algumas teorizações sobre raça, os estudos de Linné (1788 apud MUNANGA, 2003) são explícitos ao categorizar e hierarquizar quatro grupos humanos: o americano, asiático, africano e europeu. Este último a quem o estudioso atribui o degrau mais elevado de dominação e força, as características da raça são: branco, musculoso, engenhoso, inventivo, governado pelas leis. $\mathrm{Na}$ última esfera encontra-se o africano, cujos adjetivos e marcas são: negro, flegmático (descansado, vagaroso), astucioso, preguiçoso, negligente, governado pelos seus chefes (despotismo), sua mulher tem a vulva pendente e quando amamenta seus seios se tornam moles e alongados.

Além dessa hierarquização o contexto brasileiro aos olhos do branco europeu sofria de outro mal: a miscigenação, que trazia ao mundo seres híbridos, sem uma identidade cultural, porque “[...] o clima tropical do Brasil estimulava a miscigenação e, portanto, sua deterioração racial” (DIWAN, 2011, p.76).

Mesmo ao abandonarmos o uso conceitual de raça para caracterizar o contingente da população negra no Brasil e passarmos a usar etnia, não seria possível ainda afirmar que tal uso estaria melhor aplicado, pois para que um grupo humano possa 
ser considerado da mesma etnia teria que falar a mesma língua, possuir similaridades culturais, provenientes de uma mesma região; no entanto a historiografia brasileira demonstra que nosso país recebeu ao longo do período escravocrata, negros oriundos de várias tribos e regiões da África, cada qual com sua cultura, língua, religião, hábitos e modos de organização, dentre eles: Bantos, Jêjes e Iorubás.

O que justifica o uso do termo culturas afro-brasileiras, e não no singular, pois o Brasil configura-se como o país mais africano fora da própria África, onde em cada região de nossa nação a presença africana imprimiu jeitos próprios de se manifestar, além de adquirir a influência das culturas indígenas e europeias.

Apesar da superação teórica do uso de "raça” para designar diferentes grupos humanos, e fazer uso de etnia, que representa melhor as várias e diferentes culturas da Terra, no Brasil ainda é a cor da pele, principalmente que provoca a manifestação do racimo, ainda que velado e da discriminação para com esse contingente populacional que representa metade da população. Por isso é necessário que na vida concreta das relações sociais, se supere também o uso da raça, do racismo, da verticalização racial tão presentes no imaginário nacional e nos próprios documentos legais que tratam do tema, na próxima sessão discutiremos melhor esse assunto.

\section{A realidade "racial” brasileira}

A historicidade do Brasil torna necessário o uso da terminologia raça, fora da Biologia, ela deve ser compreendida como um conceito sócio-histórico construído nas relações de poder, ou seja, é constructo-social, perversamente usado para alocar os sujeitos negros na condição de subalternidade, Gomes (2000) esclarece que "Raça é aqui entendida com um conceito relacional que se constitui histórica, política e culturalmente” (GOMES, 2000, p.85). No dicionário o vocábulo raça assume os seguintes significados:

Sucessão de ascendentes e descendentes de uma família, um povo; geração: raça de Davi. Grupo de indivíduos cujos caracteres biológicos são constantes e passam de uma a outra geração: raça branca, raça negra, raça amarela, raça vermelha. História natural, subdivisão de uma espécie: raças humanas. Categoria de pessoas da mesma profissão, de inclinações comuns: os usurários constituem má raça. (Sin.: descendência, família, linhagem, geração, estirpe, classe.) Animal de raça, animal de boa origem (DICIONÁRIO ELETRÔNICO, grifo nosso). ${ }^{7}$

${ }^{7}$ Disponível em: <http://www.dicio.com.br/raca/>. Acesso em: 6 abr. 2012. 
Por outro lado, o dicionário Houaiss e Villar (2009, p.1602) já apresenta algumas mudanças na apresentação do significado do termo, buscando denunciar a sua arbitrariedade quando aplicado aos seres humanos: “1. Divisão tradicional e arbitrária dos grupos humanos, determinada pelo conjunto de caracteres físicos e hereditários (cor da pele, formato da cabeça, tipo de cabelo etc.)”

Essas evidências explicam a negação do racismo brasileiro. Permite-nos analisar com um grau maior de complexidade os termos preconceito e discriminação, que são refletidos numericamente ao comparar as condições sociais, econômicas, de escolarização e profissionalização ${ }^{8}$ entre negros e brancos. Para Filice,

\begin{abstract}
Nesse contexto exige-se a referência à categoria raça como um constructo social e considerar o preconceito e a discriminação racial como conceitos empíricos originários de raça, que permitem analisar um fenômeno cultural e social mais complexo, ainda que na sociedade brasileira a cultura do racismo seja negada (FILICE, 2011, p.33).
\end{abstract}

O país caminha por reconhecer ao menos a segregação racial que minou a todo custo à participação efetiva da população afro-descendente na educação e por conseqüência, no mercado de trabalho. A evidência disso foi a publicação de leis antiracistas, como a Lei 10.639/2003 (BRASIL, 2003), que acrescentou o artigo 26-A na Lei de Diretrizes e Bases da Educação brasileira, lei nº. 9394/96 (BRASIL, 1996), que torna obrigatório o ensino de História e Cultura Afro-brasileira em toda a Educação Básica.

Recentemente o Estatuto da Igualdade Racial (BRASIL, 2010), idealizado pela SEPPIR $^{9}$, identificado pela lei federal $12.288 / 2010$ trouxe para o campo jurídico, as ações afirmativas cujo artigo $1^{\circ}$ trata do reconhecimento pelo Estado de que a raça traz a discriminação, a saber:

I - discriminação racial ou étnico-racial: toda distinção, exclusão, restrição ou preferência baseada em raça, cor, descendência ou origem nacional ou étnica que tenha por objeto anular ou restringir o reconhecimento, gozo ou exercício, em igualdade de condições, de

\footnotetext{
8 Para maiores informações verificar a pesquisa que originou a publicação de Ricardo Henriques: HENRIQUES, R. Raça e Gênero no sistema de ensino: os limites das políticas universalistas na educação. Brasília: UNESCO, 2002.

${ }^{9}$ Secretaria de Políticas de Promoção da Igualdade Racial, criada em 2003, pelo então presidente Lula, com status de Ministério.
} 
direitos humanos e liberdades fundamentais nos campos político, econômico, social, cultural ou em qualquer outro campo da vida pública ou privada;

II - desigualdade racial: toda situação injustificada de diferenciação de acesso e fruição de bens, serviços e oportunidades, nas esferas pública e privada, em virtude de raça, cor, descendência ou origem nacional ou étnica (BRASIL, 2010, p.8, grifos do autor).

Ao admitirmos raça para além da biologia e tendo seu conceito ampliado na realidade sócio-histórica brasileira percebemos que sua utilização é carregada de ideologia, expressa na concretude das relações sociais a relação de poder e dominação.

Segundo Gomes (2005), no contexto social brasileiro, substituir o termo raça por etnia, não soluciona na prática os constantes casos de discriminação, entretanto se compreendermos que a linguagem sócio-política cerca-se de ideologias para justificar a desigualdade entre pessoas, por exemplo, propomos o uso de etnia em detrimento de raça, por acreditarmos que a palavra representa a “[...] multiplicidade de dimensões e questões que envolvem a história, a cultura e a vida dos negros no Brasil” (GOMES, 2005, p. 47). Seria um caminho para contribuir com a luta anti-racista em nosso país.

Neste contexto o espaço escolar é um local privilegiado, que apesar de ter contribuído para manter este status quo de negação do racismo e de uma vivência democrática racial, ainda oferece uma excelente oportunidade para a promoção do diálogo, visando um melhor entendimento do assunto, numa busca por uma sociedade mais justa, menos excludente e que não apenas, reconheça ou respeite a cultura e o povo negro, mas que se promova uma noção positiva de pertencimento aos atores sociais brasileiros.

A seguir uma breve explicitação do percurso metodológico utilizado neste estudo: a Evocação Livre de palavras, que teve por objetivo: responder as indagações desta seção: O que as professoras dos Anos Iniciais pensam sobre os usos dos termos "raça” e "etnia”?

\section{A teoria das representações sociais: metodologia e análise dos dados gerados}

Entende-se a pesquisa em educação como um processo na perspectiva de Gatti (2010), pois está sempre se fazendo. Envolve pessoas, onde a aproximação do fatoprocesso é que será o objeto de estudo da pesquisa educacional. 
E como o processo educacional tem em seu centro pessoas, a postura do pesquisador não deve ser neutra, aliás, não conseguiria ser, pois sua concretude no mundo é que determina sua consciência, é o que o faz ser humano. Assim,

[...] sua visão de mundo, os pontos de partida, os fundamentos para a compreensão e explicação desse mundo irão influenciar a maneira como ele propõe suas pesquisas ou, em outras palavras, os pressupostos que orientam seu pensamento vão também nortear sua abordagem de pesquisa (LUDKE; ANDRÉ, 1986, p. 33).

É relevante destacar que este estudo entende que o objeto/estudo da pesquisa, na visão dialética é algo concretamente constituído, ou seja, fruto das relações sóciohistóricas do homem, o que nos permite dizer que o conhecimento é o resultado da consciência humana, e a ciência só terá sentido se for para aliviar as misérias humanas. (TRIVIÑOS, 2011).

Nesse sentido a pesquisa realizada teve o enfoque qualitativo, ou seja, com uma realidade que não pode ser explicada somente pela quantificação. Para Minayo (1994) “[...] a abordagem qualitativa aprofunda-se no mundo dos significados das ações e relações humanas, um lado não perceptível em equações estatísticas” (MINAYO, 1994, p.22). Isso porém em nada desqualifica ou torna frágil esse tipo de abordagem, que deve seguir com rigor na busca pelo reconhecimento da realidade e na produção do conhecimento científico.

Esclarecemos também que por melhor que seja determinado quadro de referência ou epistemologias e métodos de pesquisa, acreditamos nas ideias de Feyerabend (2011) ao defender o pluralismo epistemológico, em sua obra clássica “Contra o Método”, segundo ele: “[...] todas as metodologias, até mesmo as mais óbvias, têm seus limites” (FEYERABEND, 2011, p.47).

A terminologia "Representação Social” foi cunhada por Serge Moscovici, um psicólogo francês, após estudos sobre a representação social da psicanálise.

Nos anos 60, Moscovici (1978) passa a criticar a abordagem hegemônica da Psicologia Social em que a mesma só focava no estudo isolado das atitudes. O autor francês defendia que a atitude é um elemento das representações sociais, portanto não pode ser estudada de maneira isolada.

Aprimorando suas pesquisas, Moscovici (1978) retoma o conceito de Representação Coletiva proposto anteriormente por Émile Durkheim (1999) para 
designar a especificidade do pensamento social em relação ao pensamento individual. A intenção de Durkheim era dar ao senso comum um novo status epistemológico.

Já Moscovici, teve a preocupação de afirmar que os indivíduos fazem parte de um processo de mundo dinâmico e que não se vislumbra uma cisão entre sujeito e objeto. Assim, o autor propõe que consideremos representação como fenômeno e não como conceito.

Avançando no estudo das representações, Abric (2001) desenvolve o método de associação ou evocação livre de palavras, que consiste em solicitar aos interlocutores (por meio de um questionário) que, estimulados por um termo indutor respondessem a questão-

Os dados foram gerados em uma escola pública de anos iniciais, localizada na Região Administrativa de Ceilândia, DF e teve como interlocutoras oito professoras, sendo quatro classificadas como brancas e as outras como negras ${ }^{10}$, todas formadas em Pedagogia e atuando nos anos iniciais do Ensino Fundamental há mais de dez anos.

Os instrumentos para levantamento dos dados foram: Uma produção textual baseada na leitura de uma imagem, onde foi solicitado: “O que você pensa ao observar esta foto? Escreva um texto apresentando suas ideias”.

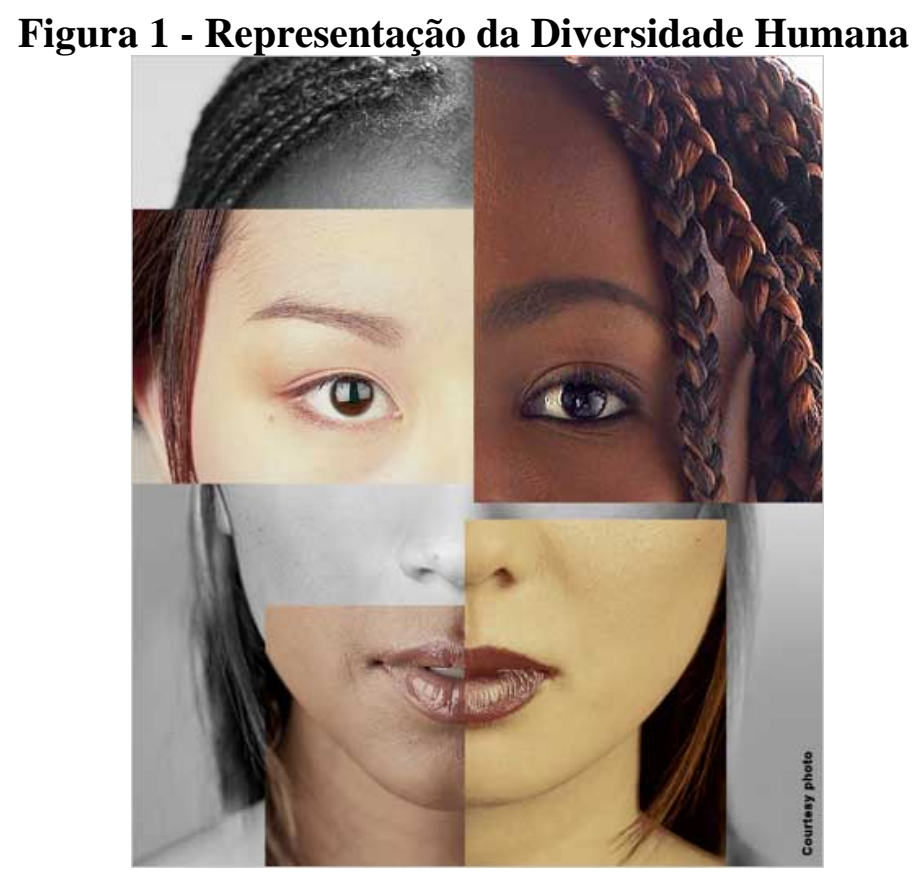

Fonte: Disponível em: <http://lagcast.com.br/wpcontent/uploads/2012/03/012208_womenRW_500.jpg?cda6c1>. Acesso em: 2 mai. 2012.

10 Apesar de o IBGE - Instituto Brasileiro de Geografia e Estatística adotar o critério de autoclassificação, por questões conceituais da própria pesquisa, preferiu-se a classificação feita com bases no fenótipo de cada interlocutora. 
Houve também o preenchimento de um questionário que continha a técnica da associação livre de ideias, em seguida a hierarquização sucessiva. E teve como objetivo o levantamento do conteúdo das representações sociais.

Em nossa pesquisa foi solicitado às professoras que indicassem cinco palavras para o termo indutor "raça” (etnia). A seguir elas indicaram as três palavras mais importantes citadas na questão um, e por último deveriam indicar a/s palavra/s ou termo/s mais representativo/a/os/as.

\section{“Raça” (etnia) e a representação social: apresentação e discussão dos resultados da pesquisa}

Com base nos instrumentos aplicados para gerar os dados optamos por analisar inicialmente as respostas do texto solicitado e por último os resultados alcançados a partir da aplicação do questionário, que continha a Associação Livre de Palavras e a hierarquização sucessiva das mesmas.

Organizamos as participantes em dois grupos: 1 - professoras negras (PN) (de 1.1 a 1.4) e 2 - professoras brancas (PB) (2.1 a 2.4).

Ao solicitar que o grupo um escrevesse um texto sobre a imagem, apresentamos algumas respostas que surgiram:

“Todos os povos, de todas as raças, cor, credo e ideologias formam a humanidade. Somos um só povo, o que somos não se mostra na cor da pele ou nas características físicas, e sim nas atitudes” (PN, 1.1).

"Que as pessoas seriam mais felizes se não houvesse distinção de cor, credo e raça” (PN, 1.3).

No grupo 2, das professoras brancas (PB), as reflexões que apareceram foram:

\footnotetext{
"Deste ponto de vista o racismo imperante no Brasil não faz sentido nenhum, pois desconsidera toda a contribuição dos diversos povos que pelos mais diversos motivos chegaram e se instalaram neste país” (PB, 2.2)

"Mesmo com a mistura de raças ainda hoje a discriminação acontece em todas as esferas da nossa sociedade" (PB, 2.3)

"E embora o conceito 'raça' seja novo o preconceito vem de longo tempo é incrível como ainda hoje com tanta informação nos deparamos com histórias absurdas de discriminação” (PB, 2.4).
} 
Ao analisar as respostas acima é possível depreender como ainda na percepção das interlocutoras a palavra "raça" apareceu fortemente relacionada com os grupos étnicos presentes na sociedade brasileira, sem, no entanto a palavra "etnia” ter sido mencionada em nenhum dos textos. E mais, discriminação e preconceito foram evocados em dois textos, o que nos leva a acreditar que as pessoas associam raça, racismo, preconceito com seu conceito teórico cravado na história do povo brasileiro, ainda dividido em "raças", prova disso é o uso do termo nas leis relativas às Ações Afirmativas (como o Estatuto da Igualdade Racial (BRASIL, 2010), apresentado anteriormente) e sobre a Educação das Relações Étinico-Raciais.

Infere-se, portanto, que o povo negro ainda é visto como "raça” no Brasil, desprovida das mesmas condições de oportunidades sociais, trabalhistas e educacionais, portanto uma “raça inferior”. Finalmente, a maioria dos textos não apontou para o uso biológico da raça ou mesmo seu uso equivocado para designar grupos humanos. Com exceção das seguintes assertivas:

A primeira trouxe um elemento da biologia genética associado à imagem: “[...] cada um de nós é uma pessoa diferente com um D.N.A único e com uma combinação única de características. E aí a diversidade.” (PN, 1.2) . No entanto, ao finalizar o texto a professora chama a atenção para a necessidade de aceitar essas diferenças por meio de "Bastante estudo, conscientização para que o ser humano possa compreender e aceitar essas diferenças” (PN, 1.2).

Na segunda há nas entrelinhas uma defesa pelo uso do termo "humanidade” e a exclusão de “raça” para caracterizar fenotipicamente pessoas diferentes, a saber: "Que todos somos um... Que todos os povos, de todas as raças, cor, credo e ideologias formam a humanidade” (PN, 1.1).

Mesmo a biologia e a genética tendo derrubado por meio de muitos estudos e pesquisas o argumento de raças superiores e inferiores, as invocações textuais nos levam a concluir que a maioria das pessoas percebe "raça" como sendo o termo utilizado para diferenciar grupos humanos, principalmente pelas suas características físicas, ou seja, a raça aparece como sendo um conceito construído socialmente. Concordamos com o argumento de SANTOS (2009, p.10) ao defender que, “Todavia, o fato de o termo ser largamente utilizado na identificação dos grupos humanos nos permite dizer que o conceito 'raça' foi construído socialmente para indicar lugares hierarquizados, muito embora não tenha comprovação científica”. 
Para aprimorar a pesquisa apresentaremos e discutiremos os resultados do questionário de evocações de palavras.

Na primeira questão, que tinha como termo indutor "raça” (etnia), as professoras indicaram cinco palavras que melhor representavam o termo indutor. Após leitura e análise das respostas, foi construída a Tabela 1, na qual estão quantificadas as palavras que foram evocadas, no mínimo duas vezes, os resultados foram o seguinte:

Tabela 1 - Palavras evocadas pelas professoras na questão um

\begin{tabular}{l|l}
\hline Atributo & Quantidade de Evocações \\
\hline Características & 2 \\
\hline Cor & 2 \\
Discriminação & 2 \\
\hline Grupo & 2 \\
Luta & 2 \\
\hline Preconceito & 3
\end{tabular}

Fonte: Elaboração própria.

Vale ressaltar que na última questão que solicitava apenas UMA palavra para representar o termo indutor, surgiram às seguintes: povo, garra, luta, diversidade, desumanidade. O destaque se deu com a palavra "características”, tendo aparecido três vezes.

No entanto sabendo dos limites da metodologia aplicada, não podemos afirmar se essas “características” evocadas foram associadas com o físico-biológico (cor de pele, olhos, cabelo, formato do crânio e da face) ou com o sócio-cultural (costumes, origem, língua, hábitos, religiosidade).

Porém nos é permitido deduzir que a maneira como essas características (biológicas ou culturais) são pensadas e materializadas na vida social é que nos demonstra que no Brasil, "raça” (etnia) ainda é associada à luta histórica de uma minoria silenciada, o povo afro-brasileiro, que desde sua escravização tem lutado por sua liberdade e pelo seu reconhecimento enquanto cidadão brasileiro, que mesmo após o ano de 1888, ainda não se refletiu nas condições sociais de acesso aos direitos básico ${ }^{11}$ :

\footnotetext{
${ }^{11}$ Sobre condição social e econômica da população negra no Brasil, principalmente no acesso à educação, ver as obras de Henriques (2002), Santos, J. A. dos (2010) e Filice (2007).
} 
moradia, saúde, educação, emprego, se comparados numericamente com a população não negra.

Entendemos que a educação é uma instituição fundamental para provocar mudanças estruturais na sociedade por meio do conhecimento sistematizado, mudanças que reflitam para uma sociedade menos excludente, mais justa, combativa dos preconceitos, principalmente os dirigidos à população afro-descendente.

Portanto foi fundamental perceber que a maioria das professoras dos Anos Iniciais reconheceu como a sociedade nacional possui ainda suas bases em concepções europeias, racistas e racializadas, que penalizam o negro, ainda que isso seja negado, até mesmo na escola. Saber como e se, essas educadoras tem tratado a questão da Educação das Relações Étnico-Raciais no seu cotidiano pedagógico é importante, embora necessite de outro estudo mais aprofundado.

\section{Considerações finais}

Ao longo do artigo, procuramos definir conceitualmente a origem e os usos dos termos “raça” e "etnia”, baseando-se no que a biologia genética, a sociologia, a antropologia e a história discutiram a cerca dos mesmos, pautando o debate na educação. Nosso olhar se deteve em tentar interpretar como no Brasil o uso do termo “raça” ainda é amplamente utilizado, mesmo com a desconstrução da biologia genética, esclarecendo ser equivocado seu emprego para caracterizar e diferenciar populações humanas.

O que percebemos ao utilizar a teoria das Representações Sociais - tendo com interlocutoras professoras (brancas e negras) dos Anos Iniciais por meio do instrumento de questionário, ancorado na perspectiva das evocações de palavras- é que em nosso território, percebemos o quanto “etnia” seria mais bem empregado para designar nossa população tão miscigenada. Porém, nossa própria história encarregou-se de demonstrar que não vencemos ainda o paradigma do “racismo velado” e da “cordialidade racial”, que sustentam boa parte do imaginário coletivo.

Evidências não faltam para sustentar nosso argumento: desigualdade de oportunidades de acesso, principalmente na educação para brancos e negros, aumento das denúncias de casos de injúria racial, a própria existência de leis, como Ações Afirmativas que tencionam promover uma Educação das Relações Étnico-Raciais, demonstram que ainda estamos longe de vislumbrar uma sociedade com uma origem 
étnica comum: a brasileira, ainda que com fortes influências dos povos indígenas, dos europeus colonizadores e dos vários grupos africanos escravizados aqui.

Para tanto é preciso identificar, analisar e debater sobre as tipologias de concepções encontradas no interior das escolas sobre raça. Em seus múltiplos sentidos, não se esquecendo da concretude da história brasileira, que marginalizou e excluiu boa parte de sua população, principalmente a negra. Mais um motivo para que esse estudo, defendendo o uso do termo etnia, sirva como mecanismo inicial, ao lado de tantos outros, para fomentar os debates em torno da Educação das Relações Étnico-Raciais e sua efetiva implementação na educação, ciência responsável por contribuir para uma emancipação humana, livre de preconceitos e discriminações.

\title{
EDUCATION AND "RACE" (ETHNICITY): PERCEPTIONS OF EDUCATORS OF THE EARLY YEARS OF THE PUBLIC SCHOOLS OF THE FEDERAL DISTRICT
}

\begin{abstract}
This article presents the results of a micro research and demonstrations which articulated theories about the various conceptions of the term "race" throughout the history of humanity, especially from the viewpoint of biology geneticist, but that was not hegemonic, and manifestations of socio-historical concept, with the backdrop of the history of african-Brazilian people and the racial hierarchy attempts occurred in Brazil. The study was done through literature review and methodologically with questionnaires in a school of the Public Education of the Federal District. The subject was approached from the perspective of reflexive authors: Barbujani (2007), Diwan (2011), Munanga (2003), Gomes (2001), Filice (2011) and others. The theoretical reference was the Theory of Social Representations of Moscovici (1978) and structural approach through evocations of Abric (2001). The survey instrument used was a questionnaire that contained the technique of free association, then the successive hierarchy. The goal was to try to identify the perceptions of eight teachers in the first years of elementary school in the District Federal Public Network about the concept of "race" (ethnicity) and its historical and social implications in the formation of these subjects, regarding the education of relations ethnic-racial, reifying the role of schools, that points to an antiracist education. The survey results showed the use of terminology such as race still being linked to different characteristics of people who formed Brazil, being understood as a socio-historically constructed concept. And the limited use of race to designate the set of people who have characteristics beyond the physical (culture, language, customs, religion).
\end{abstract}

KEYWORDS: Race. Ethnicity. Hierarchy. Anti-racism. 


\section{REFERÊNCIAS}

ABRIC, J-C. O estudo experimental das representações sociais. In: JODELET (Org.). As representações sociais. Rio de Janeiro: EdUERJ, 2001. p.155-171.

BARBUJANI, G. A invenção das raças: existem mesmo raças humanas?: diversidade e preconceito racial. São Paulo: Contexto, 2007.

BERNARDINO, J. Levando a raça a sério: ação afirmativa e correto reconhecimento. In: BERNARDINO, J.; GALDINO, D. (Org.). Levando a raça a sério: ação afirmativa e universidade. Rio de Janeiro: DP\&A, 2004. p.15-38.

BRASIL. Estatuto da Igualdade Racial. Lei ${ }^{\circ}$ 12.288, de 20 de julho de 2010. Institui o Estatuto da Igualdade Racial; altera as Leis $\mathrm{n}^{\mathrm{os}}$ 7.716, de 5 de janeiro de 1989, 9.029, de 13 de abril de 1995, 7.347, de 24 de julho de 1985, e 10.778, de 24 de novembro de 2003. Diário Oficial, Brasília, DF, 20 jul. 2010. Disponível em:

<http://www.planalto.gov.br/ccivil_03/_Ato2007-2010/2010/Lei/L12288.htm>. Acesso em: 5 fev. 2014.

BRASIL. Lei $n^{\circ} 10.639$, de 9 de janeiro de 2003. Altera a Lei no 9.394, de 20 de dezembro de 1996, que estabelece as diretrizes e bases da educação nacional, para incluir no currículo oficial da Rede de Ensino a obrigatoriedade da temática "História e Cultura Afro-Brasileira", e dá outras providências. Diário Oficial, Brasília, DF, 9 jan. 2003. Disponível em: <http://www.planalto.gov.br/ccivil_03/leis/2003/110.639.htm>. Acesso em: 5 fev. 2014.

BRASIL. Lei n ${ }^{\circ}$ 9.394, de 20 de dezembro de 1996. Estabelece as diretrizes e bases da educação nacional. Diário Oficial, Brasília, DF, 20 dez. 1996. Disponível em: <http://www.planalto.gov.br/ccivil_03/leis/19394.htm>. Acesso em: 5 fev. 2014.

\section{CHAMBERLAIN, H. S. Correspondência sobre assuntos políticos da Alemanha e} apoio às ideias de Hitler [carta]. Bayreuth, Alemanha, 07 out. 1923. Para Adolf Hitler.

DIWAN, P. Raça Pura: uma história da eugenia no Brasil e no mundo. São Paulo: Contexto, 2011.

DURKHEIM, É. As regras do Método Sociológico. 2.ed. São Paulo: Martins Fontes, 1999.

FEYERABEND, P. K. Contra o método. São Paulo: Editora Unesp, 2011.

FILICE, R. C. G. Raça e classe na gestão da educação básica brasileira: a cultura na implementação de políticas públicas. Campinas: Autores Associados, 2011.

Identidade fragmentada: um estudo sobre a história do negro na educação brasileira 1993 - 2005. Brasília: INEPE, 2007.

FREYRE, G. Casa-Grande \& Senzala. 34.ed. Rio de Janeiro: Editora Record, 1998. 
GATTI, B. A. A construção da pesquisa em educação no Brasil. Brasília: Líber Livro Editora, 2010.

GOBINEAU, J.-A. de. Essai sur l'inégalité des races humaines: (1853-1855). Paris: Éditions Pierre Belfond, 1967. v.1-4. Disponível em:

$<$ http://www.google.com.br/url?sa=t\&rct=j\&q=essai\%20sur\%201\%27in\%C3\%A9galit \%C3\%A9\%20des\%20races\%20humaines\&source=web\&cd=3\&ved=0CG0QFjAC\&url =http\%3A\%2F\%2Fclassiques.uqac.ca\%2Fclassiques\%2Fgobineau\%2Fessai_inegalite_r aces\%2Fessai_inegalite_races_1.doc\&ei=dGeqT4SXOKHc0QGBhKmqBQ\&usg=AFQ jCNF71BM-dy_pO0FWJTU9rBJH5AY1Zw\&cad=rja>. Acesso em: 7 mai. 2012.

GOMES, N. L. Alguns termos e conceitos presentes no debate sobre relações raciais no Brasil: uma breve discussão. In: Educação anti-racista: caminhos abertos pela Lei Federal no 10.639/2003. SECAD-MEC. Brasília, 2005. p.39-62.

Educação cidadã, etnia e raça: o trato pedagógico da diversidade. In:

CAVALLEIRO, E. Do silêncio do lar ao silêncio escolar: Educação e Poder: racismo, preconceito e discriminação na Educação Infantil. São Paulo: Summus, 2000. p.83-96.

HENRIQUES, R. Raça e Gênero no sistema de ensino: os limites das políticas universalistas na educação. Brasília: UNESCO, 2002.

HOUAISS, A.; VILLAR, M. de S. Dicionário da língua portuguesa. 4. ed. Rio de Janeiro: Objetiva, 2009. 2922 p.

LUDKE, M.; ANDRÉ, M. Pesquisa em educação: abordagens qualitativas. São Paulo: EPU, 1986.

MINAYO, M. C. de S. Pesquisa Social: teoria, método e criatividade. Petrópolis, RJ: Vozes, 1994.

MOSCOVICI, S. A representação social da psicanálise. Rio de Janeiro: Zahar, 1978.

MUNANGA, K. Uma abordagem conceitual das noções de raça, racismo, identidade e etnia. Rio de Janeiro, 2003. Palestra proferida no $3^{\circ}$ Seminário Nacional Relações Raciais e Educação (PENESB). Disponível em:

<http://www.ufmg.br/inclusaosocial/?p=59>. Acesso em: 6 abr. 2012.

OLIVA, A. R. Lições sobre a áfrica: diálogos entre as representações dos africanos no imaginário ocidental e o ensino da História da África no mundo Atlântico (1990-2005). 2007. 404f. Tese (Doutorado em História Social) - Instituto de Ciências Humanas, Departamento de História, Universidade de Brasília: Brasília, 2007.

PENA, S. D. J.; BORTOLINI, M. C. Pode a genética definir quem deve se beneficiar das cotas universitárias e demais ações afirmativas? Estudos Avançados, São Paulo, v.18, n.50, p.31-50, jan./apr. 2004.

PENKA, K. Origines Ariacae: Linguistisch - chronolo- gische Untersuchungen zur ältesten geschichte der arischen Völker und sprachen. 1883. Disponível em:

$<$ https://archive.org/details/originesariacae01penkgoog>. Acesso em: 6 fev. 2014. 
POSCH, T. Ein Beitrag zur historischen Anthropologie [Uma contribuição à Antropologia Histórica]. Londres, 1878.

RODRIGUES, R. N. Os africanos no Brasil. São Paulo: Companhia Editora Nacional, 1977.

SALZANO, F. M. O conceito de raça a partir da biologia e da sociologia. Revista Genética na escola, Porto Alegre, v.2, n.1, p.1-2, 2007. Disponível em:

<http://geneticanaescola.com.br/vol-ii1-artigo-01/>. Acesso em: 4 fev. 2014.

SANTOS, G. Relações raciais e desigualdades no Brasil. São Paulo: Selo Negro, 2009.

SANTOS, J. A. dos. A trajetória da Educação profissional. In: LOPES, E. M. T.; FILHO, L. M. de F.; VEIGA, C. G. (Org.). 500 anos de educação no Brasil. Belo Horizonte: Autêntica, 2010. p.205-224.

SANTOS, D. J. da S. et al. Raça versus etnia: diferenciar para melhor aplicar. Dental Press Journal of Orthordontics, Maringá, v.15, n.3, p.121-124, 2010. Disponível em: <http://www.scielo.br/pdf/dpjo/v15n3/15.pdf>. Acesso em: 1 mai. 2012.

TRIVIÑOS, A. N. S. Introdução à pesquisa em ciências sociais: a pesquisa qualitativa em educação. São Paulo: Atlas, 2011.

VARCHER DE LAPOUGE , G. Les Sélections Sociales. Paris: Librairie Thorin \& Fils, 1896. 